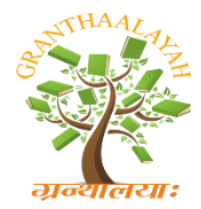

\author{
INTERNATIONAL JOURNAL OF RESEARCH \\ GRANTHAALAYAH \\ A knowledge Repository
}

Science

\title{
GEOCHEMICAL PROVENANCE AND SPATIAL VARIATION OF FLUORIDE IN GROUNDWATER OF SINDHUDURG DISTRICT, WESTERN MAHARASHTRA
}

\author{
N. Suneetha ${ }^{1}$, G. Gupta ${ }^{* 1}$, G. Shailaja ${ }^{1}$ \\ ${ }^{* 1}$ Indian Institute of Geomagnetism, New Panvel (W), Navi Mumbai 410218, India
}

\begin{abstract}
The present study focuses on the occurrence and intensity of fluoride in drinking water from the Malvan-Vijaydurg coastal tract in Sindhudurg district, Maharashtra. Concentration of fluoride $\left(\mathrm{F}^{-}\right.$ ) from 36 dug wells/bore wells sampled during this study ranged from $0.04 \mathrm{mg} / \mathrm{L}$ to $1.6 \mathrm{mg} / \mathrm{L}$. The results indicate that about $47 \%$ of the water samples from the study area have fluoride content greater than $1 \mathrm{mg} / \mathrm{L}$, which exceeds the permissible limit of BIS $(1 \mathrm{mg} / \mathrm{L})$, while 4 samples exceeded the World Health Organization standards of $1.5 \mathrm{mg} / \mathrm{L}$. Spatial variation in Fconcentration indicates that most of the sampling sites having comparatively high fluoride also have high values of $\mathrm{pH}, \mathrm{EC}$ and TDS concentration measured in groundwater. High fluoride levels are associated with $\mathrm{Ca}-\mathrm{Mg}-\mathrm{Cl}-\mathrm{SO}_{4}, \mathrm{Na}-\mathrm{Cl}$ and $\mathrm{Na}-\mathrm{HCO}_{3}$ type water produced by calcite precipitation and/or base ion exchange. The groundwater with higher fluoride concentrations is accompanied by lower $\mathrm{Ca}^{+2}$ levels. This study augments our understanding on geochemical behaviour of $\mathrm{F}^{-}$concentration and highlights the importance of spatial variability of $\mathrm{F}^{-}$in coastal aquifers. It is also pertinent to monitor the water quality periodically in this region and consequently discontinue using the wells which contain high fluoride concentration.
\end{abstract}

Keywords: Fluoride; Groundwater; Saturation Index; Konkan; Sindhudurg; Maharashtra.

Cite This Article: N. Suneetha, G. Gupta, and G. Shailaja. (2018). "GEOCHEMICAL PROVENANCE AND SPATIAL VARIATION OF FLUORIDE IN GROUNDWATER OF SINDHUDURG DISTRICT, WESTERN MAHARASHTRA." International Journal of Research - Granthaalayah, 6(5), 17-29. https://doi.org/10.29121/granthaalayah.v6.i5.2018.1416.

\section{Introduction}

Groundwater quality is a major concern today as it is mostly the only source used for drinking purpose worldwide. Tremendous strides in industrialization, urbanization and agricultural practices are primarily responsible for groundwater contamination. Apart from these, the incidence of fluoride in groundwater is also due to natural geogenic reasons. As per ${ }^{1}$, the maximum permissible limit for $\mathrm{F}^{-}$in drinking water is $1.0 \mathrm{mg} / \mathrm{L}$ whereas ${ }^{2}$ has assigned a maximum permissible limit of $1.5 \mathrm{mg} / \mathrm{L}$. 
Amongst all the chemical elements in the halogen group, Fluorine is the lightest and is one of the most reactive. It is also the most electronegative of all the elements ${ }^{3}$, which suggests that it has a strong propensity to gain a negative charge, and in solution forms $\mathrm{F}^{-}$ions. Fluoride ions have the same charge and nearly the same radius as hydroxide ions and may replace each other in mineral structures $^{3}$. Fluoride therefore forms mineral complexes with a number of cations, and some common minerals of low solubility contain fluoride.

It is reported that fluoride is found at significant levels in a wide variety of minerals, like fluorite, fluorapatite, hydroxylapatite, rock phosphate, cryolite, mica, hornblende etc. These minerals may occur in a variety of rocks including basalts, granites, gneisses, schists, charnockites, khondalites. Anthropogenic sources of fluoride include mining, chemical fertilizers, sewage, sludge etc ${ }^{4}$. Fluorite $\left(\mathrm{CaF}_{2}\right)$ is a common fluoride mineral of low solubility occurring in both igneous and sedimentary rocks. Fluoride is also usually linked with volcanic activity and fumarolic gases. Water having high $\mathrm{pH}$ is also rich in fluoride ${ }^{5}$.

In India $\mathrm{F}^{-}$above permissible limit in groundwater has been reported from parts of 19 states $^{6}$, with a combination of higher rate of evaporation and longer interaction of water with aquifer materials under alkaline environment ${ }^{7-11}$. Some anthropogenic activities such as use of fertilizers, pesticides and sewage and sludge have also been indicated for an increase in fluoride concentration in groundwater. Fluoride is known to cause significant effects in human beings from mild dental fluorosis to crippling skeletal fluorosis as the level and period of exposure increases ${ }^{12}$.

A detailed study of fluoride concentration in groundwater was carried out by different researchers ${ }^{12-14}$ amongst others in different geological formations in India. In the state of Maharashtra, high fluoride contaminated groundwater has been reported from parts of trapcovered Sindhudurg district ${ }^{14}$. These studies were mainly focused in the gneisses terrain in the coastal belt, but the occurrence of fluoride in the immediate vicinity of the coastline along the Sindhudurg district is unreported so far. The main objective of this study is to investigate the occurrence of fluoride in groundwater, both in the coastal tract and the inland parts of northern Sindhudurg district so as to assess its suitability for drinking water purposes.

\section{The Study Area}

The study area lies between $73.3^{\circ} \mathrm{E}$ and $73.8^{\circ} \mathrm{E}$ latitude and $16.0^{\circ} \mathrm{N}$ and $16.5^{\circ} \mathrm{N}$ longitude in the coastal district of Sindhudurg, Maharashtra (Fig. 1). This part of Konkan experiences heavy monsoon rains (average 2500-3500 mm/yr) and the weather is mostly humid throughout the year. Occurrence and movement of groundwater is influenced by geomorphological features such as mountains, hills, rivers, slopes, escarpments, plateaus, valleys and alluvial terrace etc, controlling the hydrogeological conditions ${ }^{15}$. This region essentially lies between the Sahyadris to the east and the Arabian Sea to the west. The area is covered by flat topography, dissected by several east-west trending ridges, some of which reach right up to the coast. The region is also traversed by several rivers, with steep gradient, which have their origin in the Sahyadris. The major rivers in this region are the Kasul, Gad, Achara, Piyali, and Kharada, flowing west-ward and meeting the Arabian Sea. These rivers also form major creeks in the study area ${ }^{16}$ (Fig. 1). 


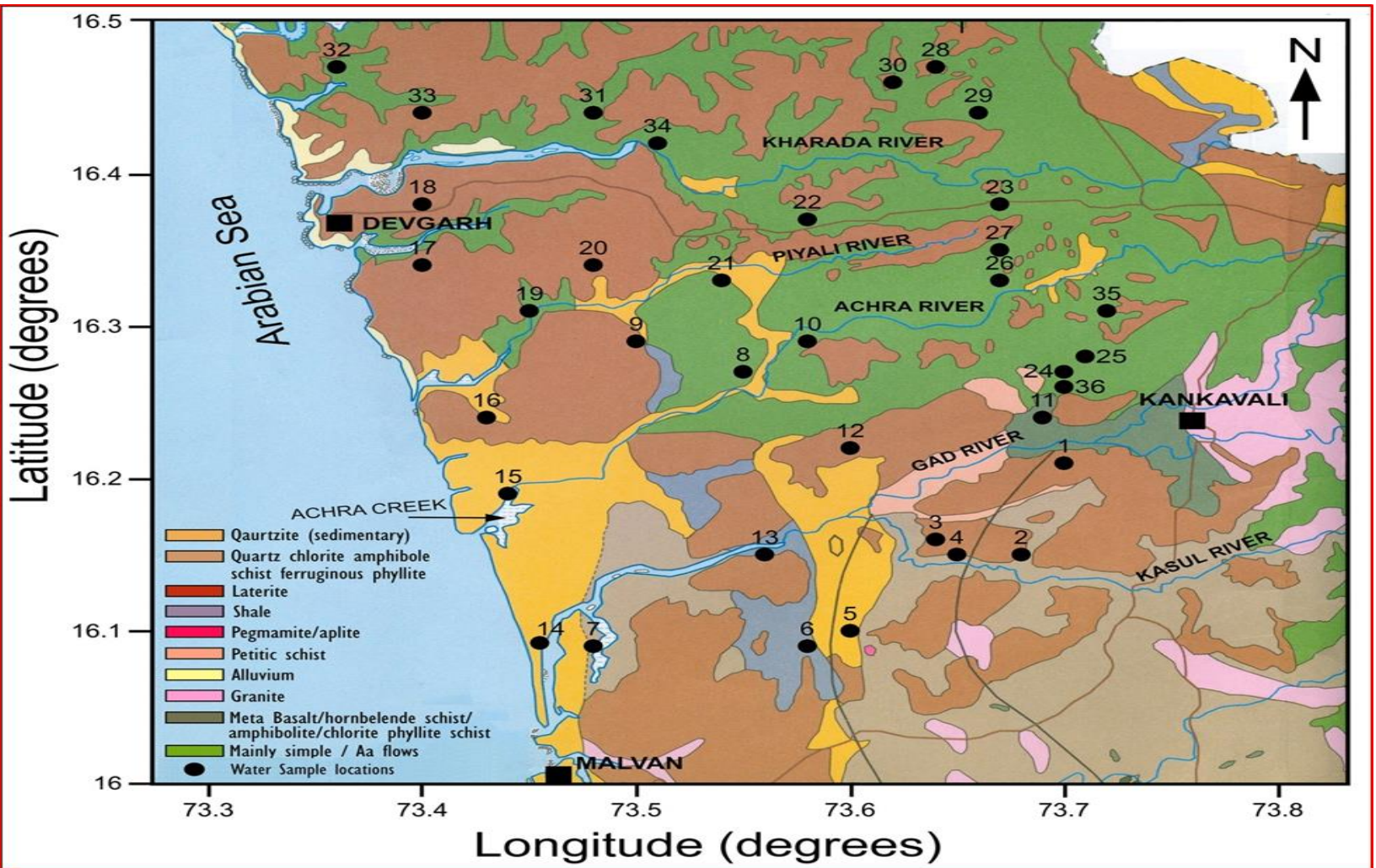

Figure 1: Location map of the study area. Also shown are the water sample sites (Redrawn $\operatorname{after}^{16}$ )

The major rock types in the area are basalt, quartzite, sandstone, shale and associated limestone, laterites and alluvium (Table 1). In Deccan Traps regions the lava flows belong to Ambenali Formation, Mahabaleshwar Formation and litho-stratigraphically into the Purandargarh Formation $^{15}$. Laterites and its soils of varying thickness are found extensively in the study area. The Deccan Traps are exposed in the eastern part, near Kankavli. Patches of quartzites are present along the coastal stretch and parts of inland. The alluvial deposits are mainly along the river course and near the sea shore. Along the Gad River basin rocks from Precambrian to Recent age are $\operatorname{exposed}^{14}$.

Table 1: General geological succession in Sindhudurg district, Western Maharashtra, India (Source CGWB report15)

Geological time Formation

Recent to sub recent
Pleistocene
Miocene
Cretaceous to Eocene
Upper Pre-Cambrian

Dharwar Super Group

\author{
Alluvium beach sand \\ Laterite and lateritic spread \\ Shale with peat and pyrite nodules \\ Deccan trap basalt lava flows \\ Kaladgi series, quartzite, sandstone \\ shale, and associated limestone
}

Phyllite, conglomerate, quartzite 
The aquifers in the region occur in weathered/fractured/jointed/vesicular/massive basalts, under phreatic and semi-confined to confined conditions. The depth to water level varies from 2 to $10 \mathrm{~m}$ below ground level (bgl) in shallow aquifers and from 20 to $50 \mathrm{~m} \mathrm{bgl} \mathrm{in} \mathrm{deeper} \mathrm{aquifers}{ }^{15}$. Rainfall is the main source of groundwater recharge in this region.

\section{Materials and Methods}

Total 36 water samples were collected during pre-monsoon period of May 2016 in the study area in order to understand the water quality. The groundwater sample locations are shown in Fig. 1. Samples are analyzed for the physico-chemical attributes like $\mathrm{pH}$, electrical conductivity (EC), total hardness (TH), total dissolved solids (TDS), major ions $\left(\mathrm{Ca}^{2+}, \mathrm{Mg}^{2+}, \mathrm{Na}^{+}, \mathrm{K}^{+}, \mathrm{Cl}^{-}, \mathrm{HCO}_{3}\right.$, $\mathrm{CO}^{3-}$ and $\mathrm{SO}_{4}{ }^{2-}$ ). The methods used for the analysis were standardized as per procedures ${ }^{17}$. $\mathrm{F}^{-}$was estimated by SPADNS spectro-photometric method.

Chemistry of the groundwater samples mainly depends on the geology as well as on the geochemical processes which take place within the groundwater system. Spatial mapping of groundwater facies based on classification of Piper ${ }^{18}$ diagram can help in visualizing the progressive fluctuations in water chemistry. In the present study, the groundwater samples were classified hydrochemically using major cations and anions with conventional Piper trilinear diagram using AquaChem 2014.2, to determine the similarities between groundwater.

Gibbs diagram ${ }^{19}$ is widely used to establish the relationship between lithological characteristics and water composition of aquifers. In this the ratio of dominant anions $\left[\mathrm{Cl} /\left(\mathrm{Cl}+\mathrm{HCO}_{3}\right)\right]$ and cations $[(\mathrm{Na}+\mathrm{K}) /(\mathrm{Na}+\mathrm{K}+\mathrm{Ca})]$ are separately plotted against TDS in order to get the possible sources of dissolved chemical constituents in groundwater aquifers from essentially three different fields such as, atmospheric precipitation dominance, evaporation dominance and rock-water interaction dominance.

Saturation indices (SI) are used to estimate the chemical stability of a mineral in water. It is a useful parameter to evaluate the equilibrium state for various solubility reactions, which describe the tendency of the solution to dissolve or precipitate in a set of minerals ${ }^{20}$. Changes in the saturation state are useful to distinguish different stages of hydrochemical evolution and help identify which geochemical reactions are important in controlling water chemistry ${ }^{21-22}$. In the

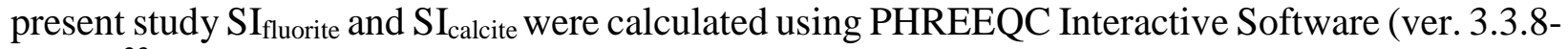
$11728)^{23}$. It is reported that if the water is exactly saturated with the dissolved mineral, SI equals to zero, while positive values of SI signify super-saturation and the mineral would tend to precipitate, and negative one implies under-saturation and the mineral would tend to dissolve ${ }^{24}$.

\section{Results and Discussions}

The statistical analysis of the chemical composition of groundwater samples are given in Table 2 . The $\mathrm{pH}$ values range between 6.2 to 8.7 with an average value of 7.2, indicating alkaline nature of water. EC and TDS ranges from $174-94920 \mu \mathrm{S} / \mathrm{cm}$ and $77-4667.0 \mathrm{mg} / \mathrm{L}$ respectively with an average value of $686.5 \mu \mathrm{S} / \mathrm{cm}$ and $335.9 \mathrm{mg} / \mathrm{L}$. The minimum and maximum values along with average values and standard deviation (SD) of $\mathrm{Na}, \mathrm{Cl}, \mathrm{Ca}, \mathrm{SO}_{4}, \mathrm{Mg}, \mathrm{CO}_{3}, \mathrm{HCO}_{3}, \mathrm{~K}$ and $\mathrm{F}^{-}$are given in Table 2. 
Table 2: Geochemical data of groundwater samples from Sindhudurg district

\begin{tabular}{|c|c|c|c|c|c|c|c|c|c|c|c|}
\hline${ }_{1}$ Wel & $\mathrm{pH}$ & $\mathrm{EC}$ & TDS & $\mathrm{Ca}$ & $\mathrm{Mg}$ & $\mathrm{Na}$ & $\mathrm{CO}_{3}$ & $\mathrm{HCO}_{3}$ & $\mathrm{SO}_{4}$ & $\mathrm{Cl}$ & $\mathrm{F}$ \\
\hline 1 & 7.48 & 317 & 144 & 28 & 9 & 15 & 40 & 67 & $\begin{array}{c}82.6 \\
1\end{array}$ & 32 & $\begin{array}{c}0.8 \\
4\end{array}$ \\
\hline 2 & 6.27 & 284 & 182 & 62 & 78 & 35 & 32 & 138 & $\begin{array}{c}90.7 \\
7\end{array}$ & 52 & $\begin{array}{c}1.2 \\
8\end{array}$ \\
\hline 3 & 7.4 & 300 & 134 & 26 & 7 & 20 & 34 & 62 & $\begin{array}{c}83.0 \\
9\end{array}$ & 48 & 0.9 \\
\hline 4 & 7 & 537 & 239 & 36 & 9 & 40 & 50 & 95 & $\begin{array}{c}109 . \\
5\end{array}$ & 53 & $\begin{array}{c}0.9 \\
6\end{array}$ \\
\hline 5 & 7.2 & 543 & 241 & 37 & 25 & 34 & 32 & 65 & $\begin{array}{c}76.8 \\
4\end{array}$ & 32 & $\begin{array}{c}0.7 \\
2\end{array}$ \\
\hline 6 & 6.95 & 333 & 149 & 21 & 15 & 18 & 4 & 73 & $\begin{array}{c}107 . \\
1\end{array}$ & 56 & $\begin{array}{c}0.9 \\
6\end{array}$ \\
\hline 7 & 7.1 & 2151 & 955 & 91 & 32 & 30 & 33 & 201 & 119 & 125 & $\begin{array}{c}0.9 \\
6\end{array}$ \\
\hline 8 & 7.44 & 186 & 84 & 53 & 15 & 10 & 32 & 48 & $\begin{array}{c}86.4 \\
5\end{array}$ & 18 & 1.5 \\
\hline 9 & 7.4 & 178 & 80 & 51 & 15 & 8 & 17 & 45 & $\begin{array}{c}146 . \\
4\end{array}$ & 36 & 1 \\
\hline 10 & 6.43 & 174 & 77 & 35 & 18 & 48 & 16 & 38 & $\begin{array}{c}183 . \\
4\end{array}$ & 42 & 0.8 \\
\hline 11 & 7 & 400 & 178 & 97 & 20 & 19 & 30 & 29 & $\begin{array}{c}205 . \\
6\end{array}$ & 28 & $\begin{array}{c}0.8 \\
4\end{array}$ \\
\hline 12 & 7.2 & 514 & 231 & 28 & 2.1 & 67 & 14 & 56 & 210 & 32 & $\begin{array}{c}0.8 \\
8\end{array}$ \\
\hline 13 & 7.62 & 187 & 83 & 39 & 7 & 41 & 26 & 87 & 79 & 15 & 1.2 \\
\hline 14 & 7.42 & 517 & 231 & 103 & 23 & 46 & 18 & 165 & 248 & 119 & 0.8 \\
\hline 15 & 7.44 & 875 & 391 & 160 & 34 & 38 & 62 & 99 & $\begin{array}{c}211 . \\
6\end{array}$ & 29 & 1.6 \\
\hline 16 & 6.74 & 246 & 110 & 22 & 16 & 39 & 34 & 144 & $\begin{array}{c}204 . \\
5\end{array}$ & 28 & $\begin{array}{c}0.9 \\
6\end{array}$ \\
\hline 17 & 7.43 & 517 & 231 & 34 & 4 & 42 & 54 & 165 & $\begin{array}{c}149 . \\
8\end{array}$ & 56 & $\begin{array}{c}1.1 \\
2\end{array}$ \\
\hline 18 & 7.05 & 338 & 151 & 65 & 13 & 44 & 34 & 68 & $\begin{array}{c}209 . \\
8\end{array}$ & 49 & $\begin{array}{c}1.0 \\
8 \\
\end{array}$ \\
\hline 19 & 6.19 & 401.7 & 179.2 & 60 & 11 & 16 & 38 & 78.68 & $\begin{array}{c}130 . \\
1\end{array}$ & $\begin{array}{c}29.3 \\
6\end{array}$ & 0.4 \\
\hline 20 & 6.38 & 255.3 & 98.13 & 76 & 14 & 9 & 30 & 71.05 & 129 & $\begin{array}{c}21.4 \\
3 \\
\end{array}$ & $\begin{array}{c}1.2 \\
4 \\
\end{array}$ \\
\hline 21 & 6.58 & 246.7 & 104.4 & 49 & 5 & 34 & 12 & 122.9 & $\begin{array}{c}86.4 \\
5\end{array}$ & 31 & 1 \\
\hline 22 & 7.1 & 325 & 143.8 & 91 & 12 & 38 & 28 & 65.12 & 126 & 21 & $\begin{array}{c}0.7 \\
1 \\
\end{array}$ \\
\hline
\end{tabular}




\begin{tabular}{|c|c|c|c|c|c|c|c|c|c|c|c|}
\hline 23 & 7.05 & 547.4 & 244 & 144 & 36 & 42 & 64 & 86 & 115 & 67 & $\begin{array}{c}1.0 \\
4\end{array}$ \\
\hline 24 & 7.15 & 620 & 277 & 25 & 9 & 50 & 36 & 130 & 131 & 39 & $\begin{array}{c}1.0 \\
8\end{array}$ \\
\hline 25 & 7.5 & 342 & 156 & 24 & 16 & 10 & 3 & 102 & 122 & 45 & $\begin{array}{c}1.2 \\
4\end{array}$ \\
\hline 26 & 7.33 & 319.4 & 139.2 & 46 & 9 & 5 & 28 & $\begin{array}{c}203.6 \\
1\end{array}$ & 184 & 15 & $\begin{array}{c}1.4 \\
8\end{array}$ \\
\hline 27 & 8 & 243 & 107.9 & 43 & 6 & 9 & 22 & 88.14 & 210 & 51 & $\begin{array}{c}1.2 \\
8\end{array}$ \\
\hline 28 & 8.66 & 440.1 & 201.3 & 52 & 5 & 21 & 14 & 41.21 & 245 & 67 & 0.4 \\
\hline 29 & 7.1 & 238.7 & 109.3 & 75 & 18 & 32 & 36 & $\begin{array}{c}156.8 \\
7\end{array}$ & 177 & 48 & $\begin{array}{c}1.5 \\
6\end{array}$ \\
\hline 30 & 6.7 & 246 & 90.6 & 28 & 7 & 23 & 18 & 62.89 & 152 & 61 & $\begin{array}{c}0.8 \\
4\end{array}$ \\
\hline 31 & 6.95 & 741.9 & 330.3 & 142 & 67 & 92 & 64 & 59.87 & 117 & 82 & $\begin{array}{c}1.4 \\
4\end{array}$ \\
\hline 32 & 7.3 & 9420 & 4667 & 640 & 107 & 108 & 12 & 82.41 & 150 & 249 & $\begin{array}{c}0.6 \\
7 \\
\end{array}$ \\
\hline 33 & 7.24 & 479 & 254 & 275 & 102 & 89 & 12 & 84 & 87 & 96 & $\begin{array}{c}0.9 \\
2 \\
\end{array}$ \\
\hline 34 & 6.8 & 346 & 139 & 90 & 57 & 34 & 34 & 35 & 110 & 35 & $\begin{array}{c}0.8 \\
4 \\
\end{array}$ \\
\hline 35 & 7.6 & 484 & 810 & 189 & 13 & 25 & 26 & 110 & $\begin{array}{c}163 . \\
2\end{array}$ & 28 & 0.9 \\
\hline 36 & 7.2 & 389 & 145 & 29 & 18 & 12 & 8 & 64 & 131 & 39 & 1.4 \\
\hline Min. & 6.2 & 174 & 77 & 21 & 2.1 & 5 & 3 & 29 & 76.8 & 15 & 0.4 \\
\hline Max. & 8.7 & 9420 & 4667 & 640 & 107 & 108 & 64 & 203.6 & 248 & 249 & 1.6 \\
\hline Mean & 7.2 & 686.5 & 335.9 & 85.2 & $\begin{array}{c}23 . \\
7\end{array}$ & $\begin{array}{c}34 . \\
5\end{array}$ & $\begin{array}{c}29 . \\
1\end{array}$ & 91.4 & $\begin{array}{c}143 . \\
6\end{array}$ & 52.1 & 1 \\
\hline SD & 0.5 & 1534.2 & 764.3 & $\begin{array}{c}109 . \\
7\end{array}$ & $\begin{array}{c}26 . \\
2\end{array}$ & $\begin{array}{c}23 . \\
9\end{array}$ & $\begin{array}{c}15 . \\
8\end{array}$ & 45.5 & 49.9 & 42.5 & 0.3 \\
\hline
\end{tabular}

From Table 2, it can be noticed that the concentration of $\mathrm{F}-$ ranges from 0.4 to $1.6 \mathrm{mg} / \mathrm{L}$ with an average value of $1 \mathrm{mg} / \mathrm{L}$. It is further observed that $47 \%$ of the water samples exceed the limit of the BIS standards $(1 \mathrm{mg} / \mathrm{L})$. However according to ${ }^{2}$, the permissible limits of $\mathrm{F}^{-}$in drinking water is $1.5 \mathrm{mg} / \mathrm{L}$. The recommended limit of $\mathrm{F}^{-}$in the water depends on the climatic conditions of an area ${ }^{25}$, because the amount of water consumed and the amount of $\mathrm{F}^{-}$ingested is influenced primarily by ambient temperature. Intake of $\mathrm{F}^{-}$below $0.5 \mathrm{mg} / \mathrm{L}$ causes dental caries ${ }^{2}$, it is reported that if $\mathrm{F}^{-}$is greater than $1 \mathrm{mg} / \mathrm{L}$, it may cause dental and skeletal fluorosis ${ }^{25}$. In the present case only two samples (well nos. 19 and 28) reveal low $\mathrm{F}^{-}$concentration of $0.4 \mathrm{mg} / \mathrm{L}$, while all other samples have values high enough to cause human damage (Fig. 2). 


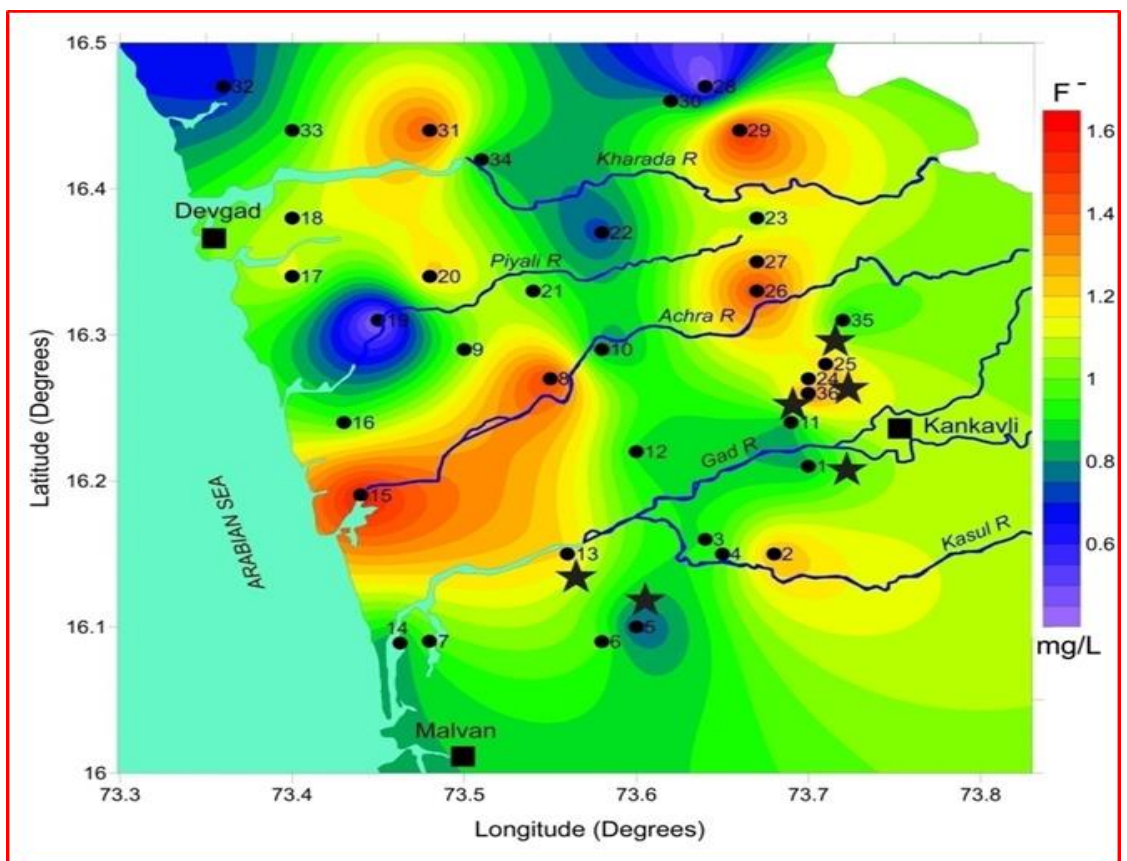

Figure 2: Spatial variation map of fluoride concentration. The closed circles are the water sample locations. Stars are the hotspots of fluoride concentration as reported by 14

\section{Spatial Distribution of Fluoride}

The spatial distribution map of fluoride in the study area is shown in the Fig. 2. In order to analyze the factors controlling the fluoride content in groundwater, one should be aware of soil cover, lithology, climate, geomorphology, anthropogenic activity and aquatic behavior (marine source). From Fig. 2, it is observed that high $\mathrm{F}^{-}$is wide-spread along the creeks and the inland part of the study area. For the sake of discussion, the study area is classified into two parts based on the sample locations: one is inland and the other is coastal. In this area, the inland part was earlier studied from parts of Gad River basin around Kankavli ${ }^{14}$. This study reported very high fluoride concentration $(5 \mathrm{mg} / \mathrm{L})$ in the groundwater over laterite, basalt and the Precambrian gneissic aquifers. High fluoride concentration is attributed to the presence of tourmaline bearing pegmatites in the Precambrian basement. Also deep circulation of fluoride-rich groundwater between the lateritised basalts and the underlying basement could be responsible for the occurrence of fluoride in both the shallow and deeper aquifers of the region. The wells sampled in that study have subsequently been abandoned. In the present study, water samples were collected from the earlier wells sampled $^{14}$. Water samples were also collected from the coastal tract. From Fig. 2 it is evident that the samples 2, 24, 25 and 36, located in the basaltic and gneissic aquifers, show relatively high $\mathrm{F}^{-}$concentration $(1.28,1.08,1.24$ and $1.4 \mathrm{mg} / \mathrm{L}$ respectively) and is greater than the BIS permissible limit. High fluoride values ranging from 1.6 to $2.5 \mathrm{mg} / \mathrm{L}$ was reported earlier in wells near to the present sampling sites $\left(2,24,25\right.$ and 36) thereby reconfirming the fluoride hotspots ${ }^{14}$. Besides these, high $\mathrm{F}^{-}$values (>1 mg/L) are observed at the sampling sites 23, 26, 27 and 29, which is located near the rivers Achara, Piyali and Khadra within the study.

The coastal tract samples $8,9,13,15,17,18,20,21$ and 31 reveals higher $\mathrm{F}^{-}$values (1.08 to 1.6 $\mathrm{mg} / \mathrm{L}$ ) along the creeks and near to sea coast. It can be noted from the above nine coastal sites that except sampling points 20, 21 and 31, others have $\mathrm{pH}$ value greater than 7, indicating alkaline nature of water (Table 2). Also sampling points 15 and 18 reveals high $\mathrm{SO}_{4}$ values (211 and 210 
$\mathrm{mg} / \mathrm{L}$ respectively), exceeding the permissible limit (200 mg/L), while station 15 also reveals high EC value $(875 \mu \mathrm{S} / \mathrm{cm})$ exceeding the permissible limit of $750 \mu \mathrm{S} / \mathrm{cm}$. Perhaps the high fluoride content at sampling point 15 is due to the sea water intrusion.

\section{Hydrochemical facies}

Hydrochemical analysis of the water samples from the study area were classified graphically using trilinear diagram (Fig. 3) in order to assess the hydrochemistry of groundwater and to establish the source of fluoride concentration ${ }^{18}$. All the major cations and anions are expressed in meq/L. The total cations are plotted on the left triangle while anions are plotted on the right triangle (Fig. 3). Each point is then projected into the upper field along a line parallel to the upper margin of the field, and the point where the extension intersects indicates the character of the water as represented by the association among $\mathrm{Na}^{+}, \mathrm{K}^{+}, \mathrm{Ca}^{2+}, \mathrm{Mg}^{2+}, \mathrm{CO}_{3}{ }^{2-}, \mathrm{HCO}_{3}{ }^{-}, \mathrm{Cl}^{-}$and $\mathrm{SO}_{4}{ }^{2-}$ ions ${ }^{26}$. From Fig. 3 it is observed that majority of the samples fall in the $\mathrm{Ca}-\mathrm{Mg}-\mathrm{Cl}-\mathrm{SO}_{4}$ and $\mathrm{Na}-\mathrm{HCO}_{3}$ type. A few samples also fall in the $\mathrm{Ca}-\mathrm{Mg}-\mathrm{HCO}_{3}$ and $\mathrm{Na}-\mathrm{Cl}$ types of water.

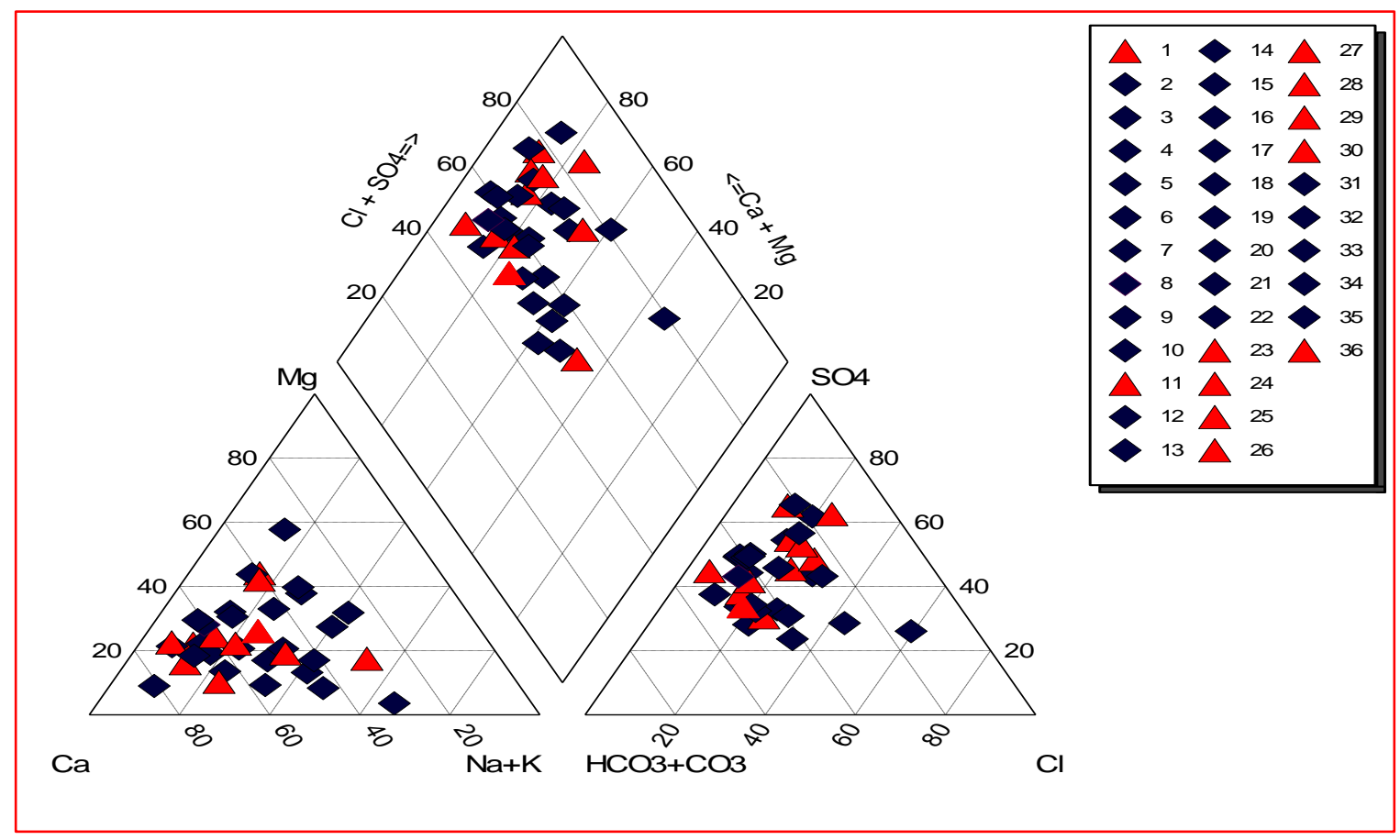

Figure 3: Hydrochemical facies of water types

\section{Rock-water interaction}

Water sample data was plotted explicitly for the purpose of understanding the prevailing controlling factors in groundwater aquifers ${ }^{19}$. From Fig. 4a,b it is evident that the grouping of data points reveal that $90 \%$ of the samples fall under the chemical weathering of rock forming minerals, which is the dominant factor controlling the groundwater chemistry in the study area, while $10 \%$ are in the evaporation domain. 


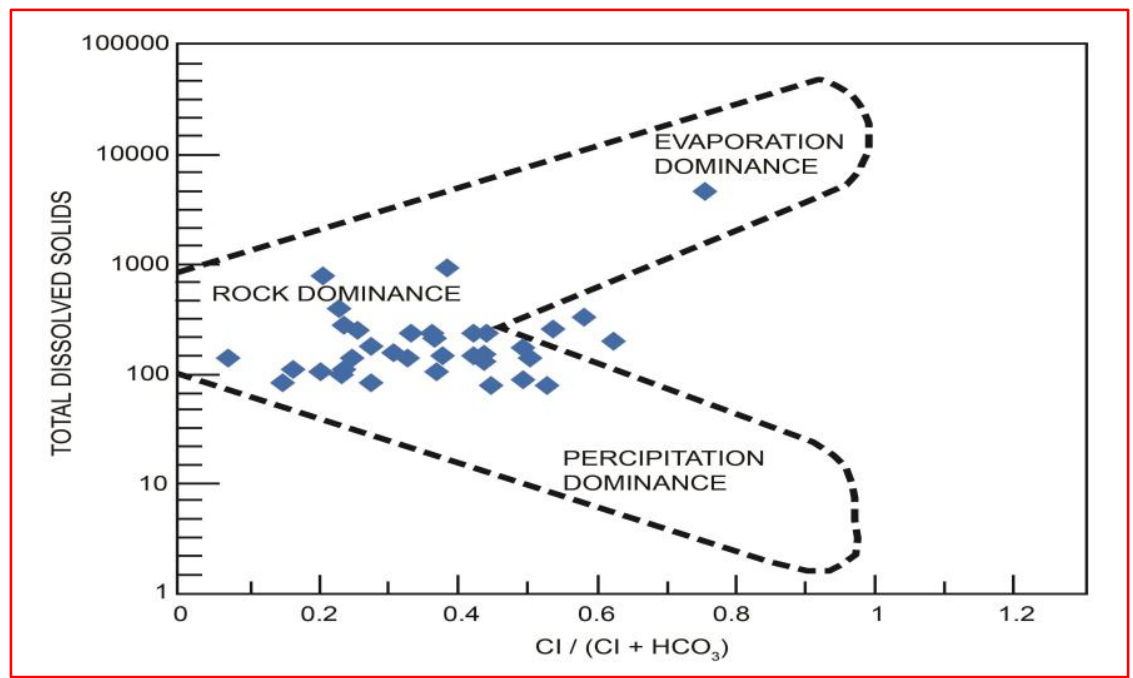

Figure 4a: Gibb's diagram of cation

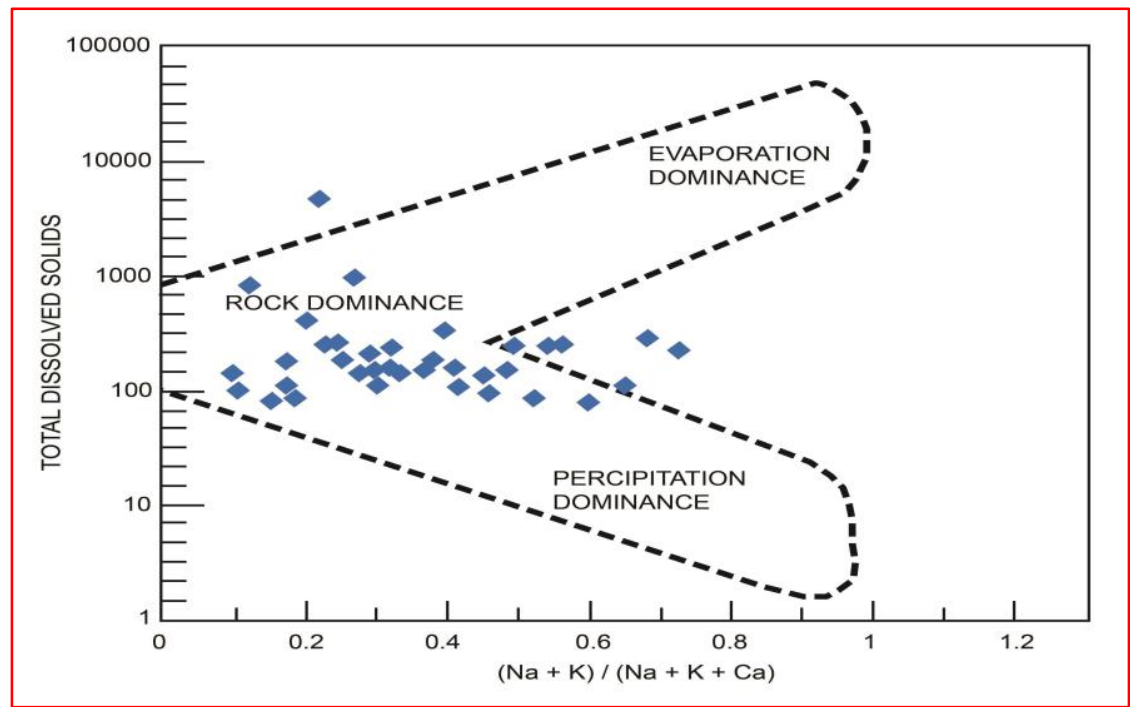

Figure 4b: Gibb's diagram of anion

The rock-water interaction phenomena are probably caused by longer residence time of groundwater. The weak evaporation dominance is a result of intensive rainfall and long-term leaching of fluorine from rocks due to weathering effects. Evaporation during summer is high and is supported by $\mathrm{Na}-\mathrm{Cl}$ type of groundwater. In the present study, fluoride concentration in the groundwater is not very high, probably as a result of heavy rainfall, leaching and/or precipitation of calcium fluoride from rocks as compared to other areas.

\section{Saturation indices of fluoride minerals}

The groundwater chemistry depends on the interaction between rain and the rock near the Earth's surface. The concept of speciation modelling has been used to study the chemical equilibrium existing in groundwater and to recognize the source of high fluoride concentration in groundwater ${ }^{27}$. The most important results of speciation calculations are saturation indices (SI) for minerals, which indicate whether a mineral dissolves or precipitates. The solubility limits for fluorite and calcite provide natural controls on water composition with a view that calcium, 
fluoride and carbonate activities are interdependent ${ }^{10}$. The data for the saturation indices (SI) of fluorite $\left(\mathrm{CaF}_{2}\right)$ and calcite $\left(\mathrm{CaCO}_{3}\right)$ in the groundwater samples were calculated using PHREEQC Interactive software and shown in Table 3.

Table 3: Saturation indices (SI) of fluorite and calcite in the groundwater samples

\begin{tabular}{|c|c|c|r|r|}
\hline Well & $\mathbf{C a}$ & $\mathbf{F}$ & SI_Fluorite & SI_Calcite \\
\hline & $\mathbf{( m g / L )}$ & $\mathbf{( m g / L )}$ & & \\
\hline & & & & \\
\hline 1 & 28 & 0.84 & -1.4551 & -0.6599 \\
\hline 2 & 62 & 1.28 & -0.9589 & -1.5958 \\
\hline 3 & 26 & 0.9 & -1.4238 & -0.8106 \\
\hline 4 & 36 & 0.96 & -1.2582 & -0.9538 \\
\hline 5 & 37 & 0.72 & -1.5338 & -0.8897 \\
\hline 6 & 21 & 0.96 & -1.4835 & -1.3469 \\
\hline 7 & 91 & 0.96 & -0.9809 & -0.187 \\
\hline 8 & 53 & 1.5 & -0.7116 & -0.5929 \\
\hline 9 & 51 & 1 & -1.081 & -0.6807 \\
\hline 10 & 35 & 0.8 & -1.4451 & -2.0995 \\
\hline 11 & 97 & 0.84 & -1.0057 & -1.0736 \\
\hline 12 & 28 & 0.88 & -1.4122 & -1.048 \\
\hline 13 & 39 & 1.2 & -1.0187 & -0.2723 \\
\hline 14 & 103 & 0.8 & -1.0732 & 0.1326 \\
\hline 15 & 160 & 1.6 & -0.3155 & 0.106 \\
\hline 16 & 22 & 0.96 & -1.4783 & -1.3009 \\
\hline 17 & 34 & 1.12 & -1.1489 & -0.2676 \\
\hline 18 & 65 & 1.08 & -0.9338 & -0.8064 \\
\hline 19 & 60 & 0.4 & -1.8035 & -1.9097 \\
\hline 20 & 76 & 1.24 & -0.7377 & -1.5745 \\
\hline 21 & 49 & 1 & -1.0815 & -1.2332 \\
\hline 22 & 91 & 0.71 & -1.1627 & -0.6313 \\
\hline 23 & 144 & 1.04 & -0.7338 & -0.4247 \\
\hline 24 & 25 & 1.08 & -1.3111 & -0.802 \\
\hline 25 & 24 & 1.24 & -1.2119 & -0.538 \\
\hline 26 & 46 & 1.48 & -0.7845 & -0.1545 \\
\hline 27 & 43 & 1.28 & -0.9197 & 0.1634 \\
\hline 28 & 52 & 0.4 & -1.8558 & 0.5545 \\
\hline 29 & 75 & 1.56 & -0.5824 & -0.3438 \\
\hline 30 & 28 & 0.84 & -1.4555 & -1.5906 \\
\hline 31 & 142 & 1.44 & -0.5264 & -0.7302 \\
\hline 32 & 640 & 0.67 & -0.7658 & 0.2921 \\
\hline 33 & 275 & 0.92 & -0.7402 & -0.0339 \\
\hline 34 & 90 & 0.84 & -1.1269 & -1.2967 \\
\hline 35 & 189 & 0.9 & -0.7125 & 0.3947 \\
\hline 36 & 29 & 1.4 & -1.0268 & -0.982 \\
\hline & & & & \\
\hline
\end{tabular}


Saturation indices (SI) of fluorite $\left(\mathrm{CaF}_{2}\right)$ and calcite $\left(\mathrm{CaCO}_{3}\right)$ are plotted in Fig. 5, which shows that except six samples (nos. 13, 15, 27, 28, 32 and 35) which accounts for $16 \%$ of water samples, all the other samples are under-saturated with respect to calcite and fluorite. The highest $\mathrm{F}^{-}$ concentrations observed are at sample nos. 13,15 and $27\left(\mathrm{~F}^{-}\right.$values $1.2,1.6,1.28 \mathrm{mg} / \mathrm{L}$ respectively), which are very near to the creeks.

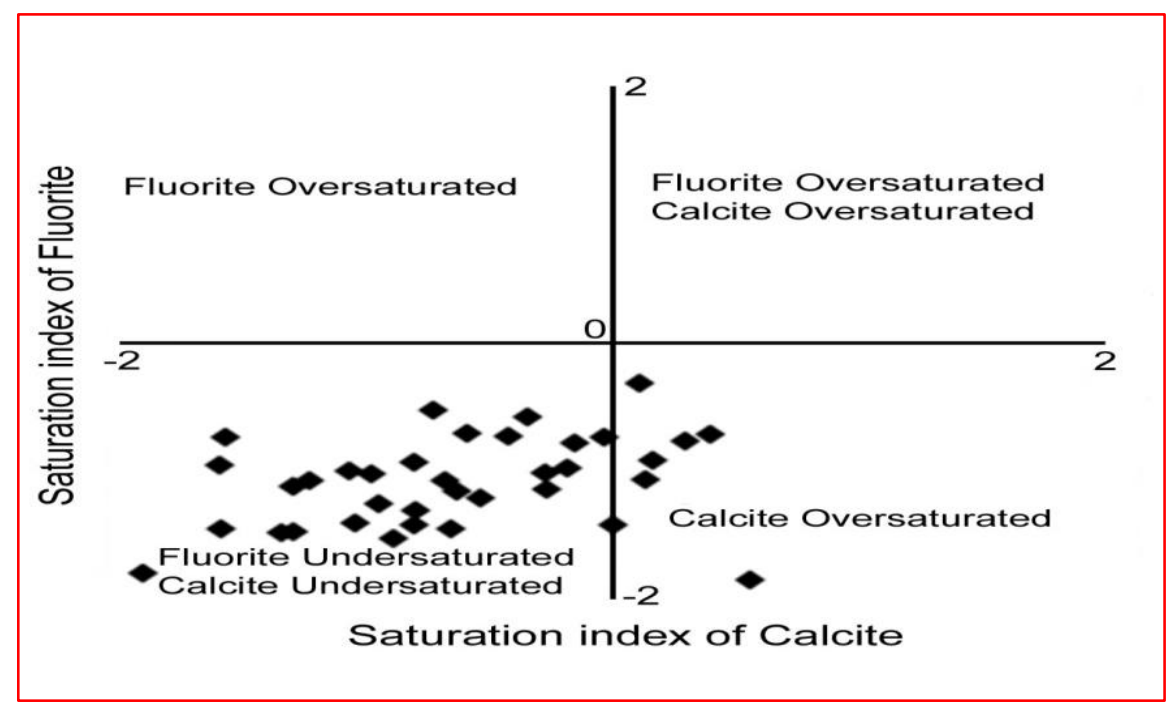

Figure 5: Plot of calcite saturation index and fluorite saturation index

Thus solubility control on the higher concentration of fluoride can be explained due to the fact that fluoride ions in groundwater can be increased as a consequence of precipitation of $\mathrm{CaCO}_{3}$ at high $\mathrm{pH}$, which removes $\mathrm{Ca}^{2+}$ from solution allowing more fluorite to dissolve ${ }^{28}$. The average $\mathrm{pH}$ in the study area is 7.2 (Table 2). The released $\mathrm{Ca}^{2+}$ ions combine with $\mathrm{CO}_{3}{ }^{2-}$ ions to further increase the precipitation of $\mathrm{CaCO}_{3}$.

It is also revealed that the samples which shows high calcite is located near to coast and is super saturated with the $\mathrm{Ca}^{2+}$. At the same time, the inland samples having high fluoride also indicate the super saturation of $\mathrm{Ca}^{2+}$, where the water type is $\mathrm{Cl}^{-}$dominant. This is replaced with $\mathrm{Ca} / \mathrm{Mg}$ by Base Exchange due to rock water interaction or evaporation which increases the ionic strength with respect to the least soluble minerals, and finally the oversaturated solution may precipitate out. This shows that Base Exchange process is an important factor for controlling the $\mathrm{F}^{-}$in the groundwater ${ }^{29}$. As mentioned earlier, six samples in the vicinity of creeks and coast reveals a positive relation between $\mathrm{pH}$ and $\mathrm{F}^{-}$. However, poor correlation between $\mathrm{pH}$ and $\mathrm{F}^{-}$observed at other sampling sites may be due to high dilution by rainwater, variable fresh-saltwater interaction in the coastal aquifers or lesser time of water residence or water-rock interaction in the aquifers ${ }^{30}$.

\section{Conclusions and Recommendations}

The groundwater of the coastal Sindhudurg district, Maharashtra was assessed for fluoride concentration, as its deficiency or excess has a direct vulnerability on human health and related societal repercussions. Therefore information regarding the status of fluoride in the coastal part of the State is crucial. The spatial variation map of $\mathrm{F}^{-}$reveals that about $47 \%$ of the groundwater samples show elevated fluoride concentration $(1.08-1.6 \mathrm{mg} / \mathrm{L})$, exceeding the BIS permissible 
limit. This study further indicated that fluoride originates from the weathering of minerals in the aquifer matrix and possibly the exchange of $\mathrm{OH}^{-}$for $\mathrm{F}^{-}$weathered rocks under high $\mathrm{pH}$ condition. Rock-water interaction is the dominant process affecting about $90 \%$ groundwater quality, which could be due to longer residence time of groundwater. About $10 \%$ samples fall in evaporation domain, owing to intensive rainfall and long-term leaching of fluorine from rocks due to weathering effects. The saturation indices of the samples reveal that they are supersaturated with respect to calcite containing high fluoride. It is possible that the removal of calcium from solution permits fluoride concentrations to increase. Some calcium is removed from solution through base ion exchange, thus increasing the fluoride concentrations associated with $\mathrm{NaCl}-$ and $\mathrm{Na}-\mathrm{HCO}_{3}$ type water.

\section{Acknowledgements}

The authors are grateful to Dr. D.S. Ramesh, Director, IIG for the encouragement and granting permission to publish this paper. The first author (SN) is indebted to IIG for the financial support in the form of fellowship. The authors are indebted to Prof. K. Vijaya Kumar of SRTM University, Nanded and Dr. R.A. Duraiswamy of Savitribai Phule Pune University, Pune for their invaluable suggestions to improve the manuscript. Thanks are also due to Dr. V.C. Erram for his help in water sample collection and to Shri B.I. Panchal for drafting the figures.

\section{References}

[1] BIS. (2012). "INDIAN STANDARD DRINKING WATER SPECIFICATION." Second Revision ISO: 10500:2012, Bureau of Indian Standards, Drinking Water Sectional Committee, FAD 25, New Delhi, India.

[2] WHO. (2008). "GUIDELINES FOR DRINKING-WATER QUALITY.” 3rd edition, Geneva, Switzerland 494p.

[3] Hem, J. D. (1989). "STUDY AND INTERPRETATION OF THE CHEMICAL CHARACTERISTICS OF NATURAL WATER." Water Supply Paper 2254, 3rd edition, US Geological Survey, Washington, D.C., 263 pp.

[4] Murray J. J. (1986). “APPROPRIATE USE OF FLUORIDES FOR HUMAN HEALTH.” World Health Organization.

[5] Edmunds, W. M., and Smedley, P. L. (2005). "FLUORIDE IN NATURAL WATERS." In Essentials of Medical Geology (ed. Selinus, O.), Elsevier Academic Press, London, 301-329.

[6] Central Groundwater Board (CGWB). (2009). "GROUNDWATER QUALITY OF SHALLOW AQUIFERS OF INDIA.” Ministry of Water Resources, Govt. of India, Faridabad, 117p.

[7] Ramamohana Rao, N. V., Suryaprakasa Rao, K., and Schuiling, R. D. (1993). "FLUORINE DISTRIBUTION IN WATERS OF NALGONDA DISTRICT, ANDHRA PRADESH, INDIA." Environ. Geol., 21, 84-89.

[8] Wodeyar, B. K., and Sreenivasan, G. (1996). "OCCURRENCE OF FLUORIDE IN THE GROUND WATERS AND ITS IMPACT IN PEDDAVANKAHALLA BASIN, BELLARY DISTRICT, KARNATAKA, INDIA- A PRELIMINARY STUDY.” Curr. Sci., 70, 71-74.

[9] Chatterjee, M. K, and Mohabey, N. K. (1998). "POTENTIAL FLUOROSIS PROBLEMS AROUND CHANDIDONGRI, MADHYA PRADESH, INDIA.” Environ. Geochem. Health, 20, $1-4$.

[10] Kundu, N., Panigrahi, M. K., Tripathy, S., Munshi, S., Powell, M. A., and Hart, B. R. (2001). "GEOCHEMICAL APPRAISAL OF FLUORIDE CONTAMINATION OF GROUNDWATER IN THE NAYAGARH DISTRICT OF ORISSA, INDIA.” Environ. Geol., 41, 451-460. 
[11] Rao, S. P., and Rao, S. N. (2014). "QUALITY OF GROUNDWATER IN A COASTAL REGION OF ANDHRA PRADESH, SOUTH INDIA.” J. App. Geochem., 16, 81-90.

[12] Handa, B. K. (1975). "GEOCHEMISTRY AND GENESIS OF FLUORIDE CONTAINING GROUNDWATER IN INDIA.” Ground Water, 13, 275-281.

[13] Kundu, M. C., and Mandal, B. (2009). "ASSESSMENT OF POTENTIAL HAZARDS OF FLUORIDE CONTAMINATION IN DRINKING GROUNDWATER OF AN INTENSIVELY CULTIVATED DISTRICT IN WEST BENGAL, INDIA.” Environ. Monit. Assess., 152, 97-103.

[14] Duraiswami, R. A., and Patankar, U. (2011). "OCCURRENCE OF FLUORIDE IN THE DRINKING WATER SOURCES FROM GAD RIVER BASIN, MAHARASHTRA.” J. Geol. Soc. India, 77, 167-174.

[15] Central Groundwater Board (CGWB). (2014). "GROUNDWATER INFORMATION, SINDHUDURG DISTRICT, MAHARASHTRA.” Technical Report 1835/DB/2014.

[16] Geological Survey of India. (2001). "DISTRICT RESOURCE MAP OF SINDHUDURG DISTRICT, MAHARASHTA." GSI, Central Region.

[17] APHA (American Public Health Association). (1998). "STANDARD METHODS FOR THE EXAMINATION OF WATER AND WASTEWATER." $20^{\text {th }}$ edition Washington, DC, 46p.

[18] Piper, A. M. (1944). "A GRAPHICAL INTERPRETATION OF WATER-ANALYSIS." Trans. Am. Geophys. Union, 25, 914-928.

[19] Gibbs, R. J. (1970). "MECHANISM CONTROLLING WORLD'S WATER CHEMISTRY." Science, 170, 1088-1090.

[20] Langmuir, D. (1997). “AQUEOUS ENVIRONMENTAL GEOCHEMISTRY.” Prentice-Hall Inc., Englewood Cliffs, 601p.

[21] Drever, J. I. (1997). "THE GEOCHEMISTRY OF NATURAL WATERS: SURFACE AND GROUNDWATER ENVIRONMENTS.” Prentice Hall, Eaglewood Cliffs, New Jersey, USA.

[22] Coetsiers, M., and Walraevens, K. (2006). "CHEMICAL CHARACTERIZATION OF THE NEOGENE AQUIFER, BELGIUM.” Hydrogeology J., 14, 1556-1568.

[23] Parkhurst, D. L., and Appelo, C. A. J. (1999). "USER'S GUIDE TO PHREEQC (VER. 2) - A COMPUTER PROGRAM FOR SPECIATION, BATCH REACTION, ONE-DIMENSIONAL TRANSPORT, AND INVERSE GEOCHEMICAL CALCULATIONS." U.S.G.S. Water Resources Investigations Report, 99-4259, Denver, USA.

[24] Hamzaoui-Azaza, F., Ketata, M., Bouhlila, R., Gueddari, M., and Riberio, L. (2011). "HYDROGEOCHEMICAL CHARACTERISTICS AND ASSESSMENT OF DRINKING WATER QUALITY IN ZEUSS-KOUTINE AQUIFER, SOUTHEASTERN TUNISIA.” Environ. Monit. Assess., 174 (1-4), 283-298.

[25] USPHS. (1987). "DRINKING WATER STANDARDS". United States Pubic Health Services Publication, Washington, DC.

[26] Raj, D., and Shaji, E. (2017). "FLUORIDE CONTAMINATION IN GROUNDWATER RESOURCES OF ALLEPPEY, SOUTHERN INDIA.” Geoscience Frontiers, 8, 117-124.

[27] Gaikwad, S. K., and Pawar, N.J. (2012). "SATURATION INDICES (SI) OF THE FLUORITE AND CALCITE OF WATER SAMPLES OF KARLI RIVER BASIN, SOUTHERN PART SINDHUDURG DISTRICT, MAHARASHTRA.” In Proceeding of International Conference SWRDM-2012, Dept. of Environmental Science, Shivaji University, Kolhapur, 185-187.

[28] Alamry, A. S. (2009). "STUDY ABOUT THE FLUOROSIS IN SELECTED VILLAGES OF TAIZ GOVERNORATE." Final Draft Mission Report prepared for NWRA, Yema, 71p.

[29] Rafique, T., Naseem, S., Ozsvath, D., Hussain, R., Bhanger, M. I., and Usmani, T. H. (2015). "GEOCHEMICAL CONTROLS OF HIGH FLUORIDE GROUNDWATER IN UMARKOT SUB-DISTRICT, THAR DESERT, PAKISTAN.” Sci. Total Environ., 530, 271-278.

[30] Duraiswami, R.A., Thigale, S. S., Pawar, N.J., and Meshram, D.C. (2000). "COASTAL ENVIRONMENT OF MAHARASHTRA: ISSUES VIS-À-VIS DEVELOPMENT." In Contributions to Environmental Geoscience, (Eds. Pathan, A. M. and Thigale, S.S.), Aravalli Books International (P) Ltd., New Delhi, 59-73. 
*Corresponding author.

E-mail address: gupta_gautam1966@yahoo.co.in 